\title{
Pengembangan Sistem Authoring Tools untuk Publikasi Jurnal Ilmiah Berbasis Web
}

\author{
Didit Setia Budi (12018200) a,1, Ardiansyah (0523077902) ${ }^{\text {b,2 }}$ \\ ${ }^{a}$ Program Studi Teknik Informatika, Fakultas Teknologi Industri Universitas Ahmad Dahlan \\ Jl. Ringroad Selatan, Kragilan, Tamanan, Kec. Banguntapan, Bantul,,Yogyakarta 55191 \\ ${ }^{1}$ diditsb007@gmail.com ; ${ }^{2}$ ardiansyah@tif.uad.ac.id
}

\begin{abstract}
ABSTRAK
Jurnal ilmiah merupakan salah satu jenis jurnal akademik dimana penulis mempublikasian artikel ilmiah. Untuk memastikan kualitas ilmiah pada artikel yang diterbitkan, suatu artikel bisa diteliti oleh rekan-rekan sejawatnya dan direvisi oleh penulis, hal ini dikenal sebagai peer review (penelaahan sejawat). Selama ini jurnal ilmiah sudah terbuka secara elektronik kemudian dikelola oleh redaksi jurnal. Pengelola jurnal ilmiah di Indonesia saat ini menggunakan Open journal system (OJS) yang dikembangkan oleh Public Knowledge Project. Kendala implementasi OJS, salah satunya adalah manajemen penerbitan secara elektronik yang belum sepenuhnya di laksanakan, baik oleh penulis, penerbit maupun mitra bestari (reviewer). Jadi bisa dikatakan penerbitan jurnal elektronik di Indonesia saat ini membuat versi cetak menjadi on-line dalam bentuk dan format $P D F$ reader. Beberapa kendala tersebut bisa diatasi dengan adanya Aplikasi authoring tools jurnal ilmiah berbasis web. Metodologi yang digunakan dalam penelitian ini yaitu melakukan pengumpulan data menggunakan metode studi pustaka dan wawancara. Kemudian dianalisis untuk menentukan kebutuhan user dan kebutuhan sistem. Implementasi aplikasi memanfaatkan Codeigniter framework dan MySql database untuk penyimpanan data. Hasil dari penelitian ini adalah pengembangan aplikasi authoring tools jurnal ilmiah berbasis web yang digunakan untuk mempermudah penulis buku dalam menulis, mereview dan mengedit konten digital berbasis web melalui peramban. Pengujian sistem dengan metode black box dengan hasil lulus dan telah sesuai dengan kebutuhan pengguna. Selain itu digunakan juga metode post-study untuk mengetahui tingkat usability aplikasi yang dikembangkan ini dengan nilai 89.58 (skala $0 . .100)$.
\end{abstract}

\section{Ciptaan disebarluaskan di bawah lisensi CC-BY-SA.}

Kata kunci: authoring tools, jurnal, e-journal, reader, web

\section{Pendahuluan}

Jurnal ilmiah merupakan salah satu jenis jurnal akademik dimana penulis mempublikasian artikel ilmiah. Untuk memastikan kualitas ilmiah pada artikel yang diterbitkan, suatu artikel bisa diteliti oleh rekan-rekan sejawatnya dan direvisi oleh penulis, hal ini dikenal sebagai peer review (penelaahan sejawat). Perkembangan jurnal ilmiah di Indonesia cukup pesat, terlebih lagi sejak diberlakukanya regulasi pemerintah, dalam hal ini Dikti yang mewajibkan mahasiswa S1,S2 hingga S3 untuk menulis artikel di jurnal ilmiah sebagai salah satu persyaratan kelulusan. Selain itu kesadaran para penerbit terkait masih rendahnya sitiran artikel jurnal ilmiah di Indonesia ikut mendorong menigkatnya animo penerbit menerbitkan artikel ilmiah secara elektronik. Sebagai media informasi, web sudah sering digunakan sebagai buku elektronik/digital [1]. Akan tetapi sampai saat ini masih jarang ditemukan jurnal yang tersedia dalam format web/HTML yang langsung bisa dibaca di peramban.

Padahal banyak penelitian yang sudah membuktikan bahwa membaca melalui dokumen web/hypertext terbukti membantu meningkatkan pemahaman konten di dalamnya [2] Sehingga 
artinya, web sudah bisa menjadi alternatif format jurnal yang bisa digunakan selain yang sudah ada yaitu bentuk cetak dan PDF. Authouring tools adalah software yang memungkinkan untuk mengembangkan konten digital dari berbagai macam media untuk menghasilkan konten digital yang interaktif dan professional. Authouring tools dibutuhkan untuk dapat mengembangkan konten digital yang dapat disesuaikan dengan kebutuhan dan dapat mengikuti dinamika perubahan sistem pembelajaran (custom content). Dengan menggunakan Authoring Tools, konten digital dapat dihasilkan dalam berbagai macam variasi bentuk publikasi seperti CD, LMS, HTML, Zip, PodCast sehingga lebih meluas jangkauannya. [3]. Authouring tools dibutuhkan untuk dapat mengembangkan konten digital yang dapat disesuaikan dengan kebutuhan dan dapat mengikuti dinamika perubahan system pembelajaran (custom content). Berdasarkan uraian latar belakang masalah serta potensi solusi yang tersedia, maka penelitian ini akan mengembangkan solusi berupa aplikasi authoring tools jurnal berbasis web. Penerapan authoring tools dalam jurnal yang akan dikembangkan yaitu mengembangkan sebuah alat bantu yang berfungsi menulis, mengedit, mereview, konten digital berbasis hypertext atau web.

\section{Landasan Teori}

Pada penelitian yang dilakukan oleh (Sinung,2014) [4], membahas mengenai Pengembangan Native Front-End aplikasi pembaca skripsi di pepustkaan kampus III UAD menggunakan android tablet. Pembuatan front-end aplikasi pembaca sekripsi ini didukung oleh native. Native itu sendiri digunakan untuk menghasilkan performa yang baik dan menghasilkan tampilan antarmuka yang baik.

[5] Penelitian yang dilakukan oleh (Singgih,2015), membahas mengenai pengembangan user experience $(U X)$ dan user interface (UI) system manajemen perpustakaan desa berbasis SAAS. Pengembangan system manajemen perpustakaan ini didukung oleh Saas. Saas adalah perangkat lunak yang berbentuk layanan service digunakan untuk membuat web perpustakaan dapat di akses oleh lebih dari satu web.

Penelitian lain dilakukan oleh (Imam, 2015)[6], yaitu mengembangkan user experience (UX) dan user interface (UI) aplikasi e-reader skripsi, tujuan penelitian ini adalah membuat sebuah rancangan antarmuka dan experience pengguna untuk aplikasi pembaca skripsi berbasis HTML5 agar aplikasi yang dibangun nantinya lebih nyaman dan mudah digunakan (user friendly). HTML5 digunakan untuk mempermudah akses yang lebih baik menggunakan tag yang dimiliki oleh HTML5 seperti header, footer, nav, section, dll memungkinkan browser untuk mengakses konten dengan mudah. Perbedaan dari pembaca skripsi PDF di PC/Tablet adalah web aplikasi pembaca skripsi ini dapat dijalan system operasi manapun, aplikasi web ini dapat dijalankan asalkan kita memiliki $n$ dan akses internet .

1. Authoring Tools

Authoring Tools merupakan sebuah perangkat lunak yang dapat digunakan untuk membuat atau menciptakan sebuah project yang meliputi unsur teks, gambar, grafik, audio atau video. Dalam hal ini authoring tools yang dimaksud berupa sebuah Teks Editor.

2. Journal Elektronik (e-Journal)

E-Journal merupakan terbitan serial seperti bentuk tercetak tetapi dalam bentuk elektronik yang biasanya terdiri dari tiga format, yaitu teks, teks dan grafik, serta full image (dalam bentuk $P D F$ ). Dalam mengembangkan layanan yang baik, perpustakaan perlu menyediakan E-Journal dalam bentuk online dengan menghubungkan ke jaringan internet yang merupakan sumber informasi dari seluruh dunia. 


\section{Hypertext}

Sebuah dokumen dapat dibuat secara statik atau dinamik. Oleh karena itu, sebuah sistem hiperteks yang dikonstruksi dengan baik dapat menangani, menggunakan atau melebihi banyak interface pengguna lainnya seperti menu dan baris perintah, dan dapat digunakan untuk mengakses kedua dokumen referensi-silang yang dikumpulkan secara statik dan aplikasi interaktif.

4. UML (Unified Modeling Language)

$U M L$ adalah bahasa grafis untuk memvisualisasi, merancang dan mendokumentasikan sistem piranti lunak [7].

5. Codeigniter

Sebuah framework PHP yang menyediakan kerangka kerja yang berupa folder maupun file-file PHP, yang didalamnya berisikan class libraries, helpers, plugins dan lainnya [8].

\section{Metode Penelitian}

\subsection{Obyek Penelitian}

Objek penelitian yang akan dibahas pada penelitian ini adalah pengembangan aplikasi authoring tools jurnal berbasis web. Aplikasi authoring tools jurnal nantinya akan digunakan mahasiswa dan umum sebagai alat bantu yang berfungsi untuk menulis, mengedit, dan mereview jurnal secara online atau berbasis web. Diharapakan aplikasi authoring tools jurnal dapat mengoptimalkan pencarian, pembacaan jurnal sebagai salah satu referensi mahasiswa dalam mengerjakan tugas akhir dan mempermudah mahasiswa dan umum untuk membuat jurnal ilmiah.

\subsection{Metode Pengumpulan Data}

Teknik pengumpulan data yang dilakukan dengan menggunakan studi pustaka dan wawancara. Studi pustaka ini dilakukan untuk mendapatkan beberapa data yang terkait dengan penelitian, seperti literatur tentang jurnal, buku tentang jurnal, jurnal yang berhubungan dengan sistem authoring tools berbasis web, dan bentuk publikasi jurnal yang ada saat ini. Wawancara dilakukan dengan mengadakan tanya jawab kepada pengurus Jurnal Sarjana Informatika Arfiani Nur Khusna, S.T., M.Kom , Mahasiswa Kampus III UAD dan umum.

Wawancara dilakukan supaya dapat diketahui secara detail dan nyata mengenai obyek penelitian termasuk keterangan, saran, proses pencarian jurnal, penulisan jurnal dan proses membaca jurnal.

\subsection{Analisis Kebutuhan}

a. Kebutuhan User

Kegiatan dalam tahap ini adalah menganalisis kebutuhan user untuk membangun sebuah authoring tools dari Sistem Publikasi Jurnal Berbasis Web sebagai media menulis, mengedit dan mereview file digital jurnal ilmiah.

b. Kebutuhan Sistem

Kegiatan dalam tahap ini adalah menganalisis kebutuhan sistem untuk membangun sistem Authoring Tools untuk publikasi jurnal ilmiah berbasis web. Kegiatan analisis mengacu pada hasil studi pustaka, observasi, wawancara yang telah dilakukan. Hasil dari analisis kebutuhan sistem ini dijadikan sebagai dasar untuk menentukan kebutuhan dari sistem yang perlu dikembangkan. hasil dari analisis kebutuhan ini dibagi menjadi dua bagian yaitu analisis kebutuhan fungsional dan analisis kebutuhan non fungsional. 
1) Kebutuhan Fungsional

Pada pengembangan Sistem Authoring Tools Untuk Publikasi Jurnal Ilmiah Berbasis Web mempunyai fungsi untuk memenuhi kebutuhan aktivitas-aktivitas yang terjadi seperti aktivitas pencarian jurnal ilmiah, penulisan jurnal ilmiah, pengeditan jurnal ilmiah dan pembacaan jurnal ilmiah dengan konten digital berupa hypertext atau web.

\section{2) Analisis Non-Fungsional}

Kebutuhan non fungsional adalah Kebutuhan yang tidak langsung berkaitan dengan fungsi-fungsi khusus yang disampaikan oleh sistem. Sistem backend publikasi jurnal ini berjalan maksimal di web. Dalam menjalankan aplikasi ini membutuhkan akses network untuk proses publikasi jurnal ilmiah [9].

\subsection{Desain Sistem}

Perancangan sistem yang dilakukan dengan menggunakan beberapa tahap:

\section{a. Use Case Diagram}

Use Case Diagram menggambarkan interaksi antara aktor-aktor dengan sistem yang dibangun, serta menggambarkan fungsionalitas yang dapat diberikan sistem kepada user. Sistem yang akan dikembangkan hanya terdapat satu aktor yaitu pengguna sebagai pelanggan.

b. Activity Diagram

Activity diagram menggambarkan aliran aktivitas dalam sistem yang dirancang.

c. Class Diagram

Class menggambarkan keadaan (atribut/properti) suatu sistem, sekaligus menawarkan layanan untuk memanipulasi keadaan tersebut (metoda/fungsi) [10].

\section{d. Struktur Tabel}

Pada tahapan ini digambarkan tabel tabel yang nantinya digunakan untuk diterapkan dalam database.

\section{e. Perancangan Interface}

Perancangan antar muka meliputi struktur menu dan output pada halaman-halaman agar nyaman digunakan serta membuat tampilan program menjadi friendly dan menarik pengguna (user) untuk menggunakannya.

\subsection{Implementasi}

Mendesain dan membuat rancangan aplikasi yang dapat diterima pengguna dan mudah digunakan serta disesuaikan dengan kebutuhan pengguna.

\subsection{Pengujian Sistem}

\section{a. Black Box Test}

Menguji yang mengabaikan mekanisme internal sistem atau komponen dan hanya berfokus pada output dihasilkan dalam menanggapi input yang dipilih.

b.Pengujian Post-Study

Dilakukan setelah user menggunakan sistem secara menyeluruh.

\section{Hasil dan Pembahasan}




\subsection{Analisis Kebutuhan}

1. Analisis Kebutuhan

Aplikasi yang dikembangkan dapat memberikan kemudahan penulis dalam menulis, mengedit dan mereview jurnal serta menpersingkat waktu proses pencarian jurnal

a. Kebutuhan User

1) User melakukan login dan registrasi sebagai penulis.

2) User dapat menambah, mengubah, dan mereview jurnal.

3) User dapat melakukan pencarian jurnal.

4) User dapat membaca jurnal.

5) User membuat jurnal .

b. Kebutuhan Sistem

1) Kebutuhan Fungsional

a) Login

b) Proses Membuat Artikel

c) Proses Pratinjau Jurnal

d) Proses save Jurnal

e) Proses Send Jurnal

f) Proses Edit Jurnal

g) Proses Baca Jurnal

h) Proses Riview Jurnal

i) Proses Pencarian Jurnal

j) Proses Beri Komentar

2) Kebutuhan Non Fungsional

a) Aplikasi hanya dapat diakses dengan menggunakan internet.

b) Sistem dapat dijalankan di semua browser yang sudah mensupport fitur-fitur HTML5 seperti Google Chrome, Firefox 3.5, Safari 4, Opera 10, Internet Explore $(6,7 \& 8)$.

c) Sistem dapat menyesuaikan tampilan web (Responsive).

\subsection{Perancangan Sistem}

a. Use Case Diagram

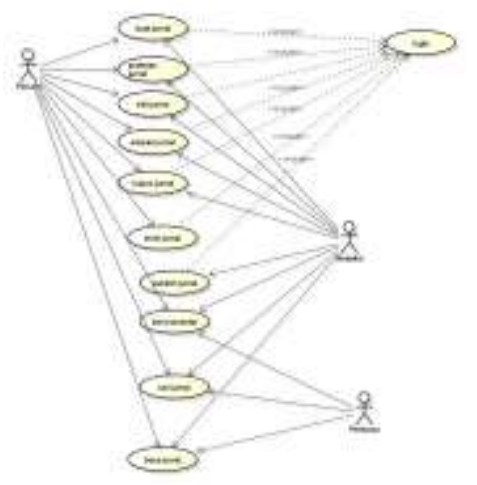

Gambar 1 : Use Case Diagram aplikasi Jurnalkita

Gambar 1 dapat dijelaskan bahwa terdapat user antara lain penulis, redaksi, dan pembaca. Pembaca memerlukan login untuk bisa menulis jurnal, sedangkan pembaca bisa langsung 
membaca jurnal secara langsung. Dan Redaksi harus melakukan login terlebih dahulu sebelum mempublish jurnal. Masing - masing user mempunyai hak tersendiri di dalam sistem. Penulis dapat membuat jurnal, dengan cara mengisi form penulisan jurnal, dapat meninjau terlebih dahulu, dapat menyimpan, dan mengirim jurnal.

b. Activity Diagram

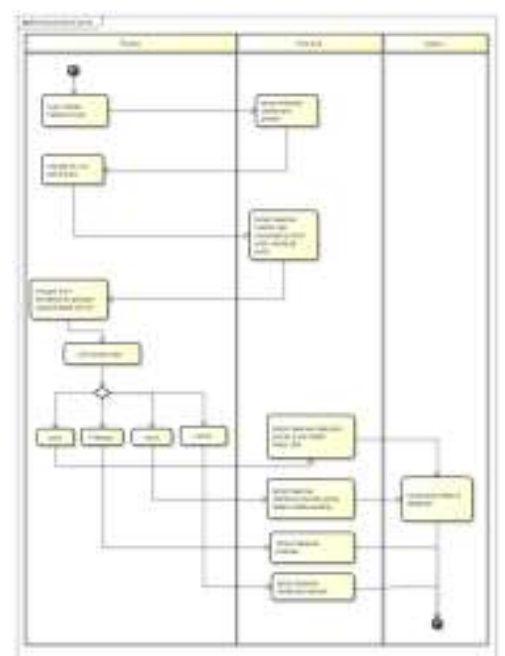

Gambar 2 : Activity Diagram Membuat Artikel Jurnal

Gambar 2 menjelaskan alur membuat jurnal yang dilakukan oleh penulis melalui sistem authoring tools.

\subsection{Implementasi}

a. Visual Mock Up

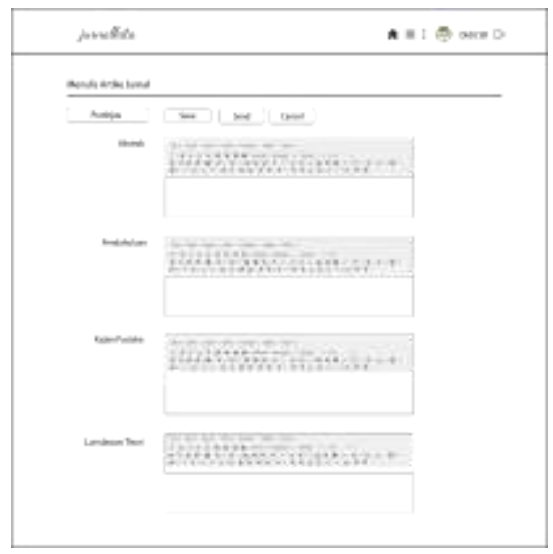

Gambar 3 : Rancangan tampilan Membuat Artikel Jurnal

Rancangan pada gambar 3 merupakan rancangan fitur Membuat Artikel Jurnal yang dilakukan oleh penulis.

b. Desain Interaksi Visual

1) Tampilan Halaman Penulis

Tampilan ini digunakan menampilkan jurnal yang diciptakan oleh penulis. Dilihat pada gambar 4. 


\section{Gambar 4 : Tampilan Halaman penulis}

2) Tampilan Membuat Jurnal

Halaman ini adalah halaman utuk penulis membuat artikel jurnal, didalam halaman ini menampilkan seperti: form input judul, nama penulis, nomer induk, email, program studi, fakultas, universitas, alamat, kategori, kata kunci, abstrak , pendahuluan , kajian pustaka,landasan teori, metode penelitian, pembahasan, penutup, dan daftar pustaka.dilihat pada gambar 5 .

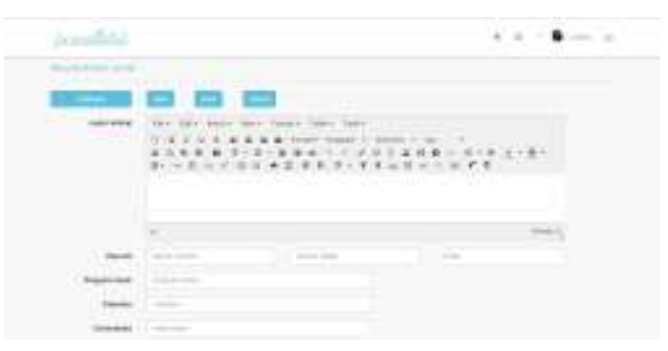

Gambar 5 : Tampilan Membuat Jurnal

3) Tampilan Edit Jurnal

Halaman ini adalah halaman untuk mengedit jurnal yang dikirim oleh penulis sebelum di publish/post, didalam halaman ini menampilkan seperti: form vol,nomer, bulan, tahun, yang dapat dilihat pada gambar 6 .

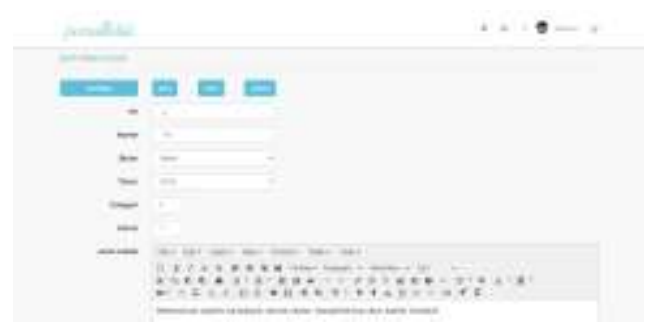

Gambar 6 : Tampilan Edit Jurnal

4) Tampilan Halaman Utama

Halaman ini adalah halamanyang pertama kali di akses oleh para user/ pembaca. Didalam halaman ini menampilkan seperti: artikel-artikel jurnal yang di publish ,menumenu dan footer dilihat pada gambar 7 .

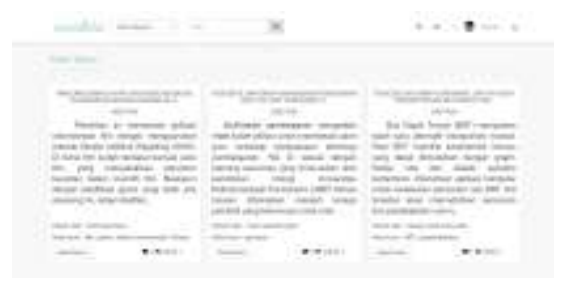

Gambar 7 : Tampilan Halaman Utama

5) Tampilan Post Jurnal

Halaman untuk mempublikasikan jurnal yang di lakukan oleh redaksi jurnal dapat dilihat pada gambar 8 . 


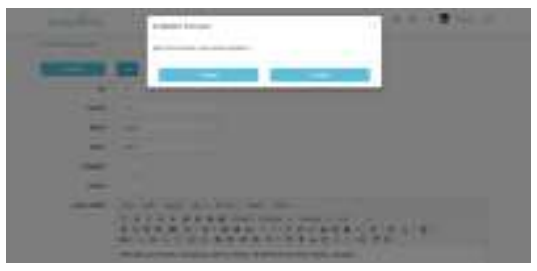

Gambar 8 : Tampilan Post Jurnal

6) Tampilan Detail Jurnal

Halaman yang digunakan menampilkan abstrak atau detail buku dapat dilihat pada gambar 9.

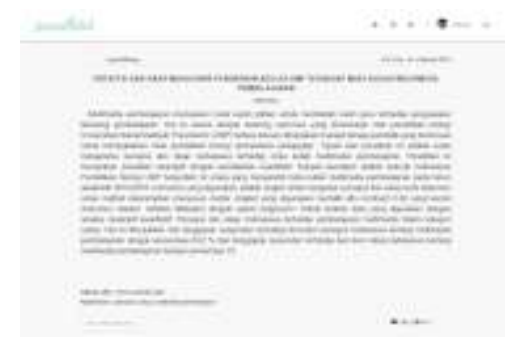

Gambar 9 : Tampilan Detail Jurnal

7) Tampilan Baca Jurnal

Halaman yang digunakan sebagai reader jurnal dapat dilihat pada gambar 10.

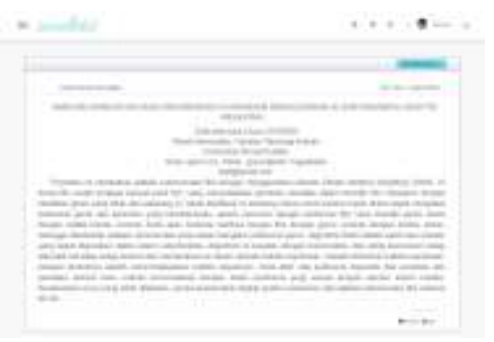

Gambar 10 : Tampilan Baca Jurnal

8) Tampilan Cari Kata

Halaman yang digunakan untuk mencari kata didalam konten reader jurnal dapat dilihat pada gambar 11 .

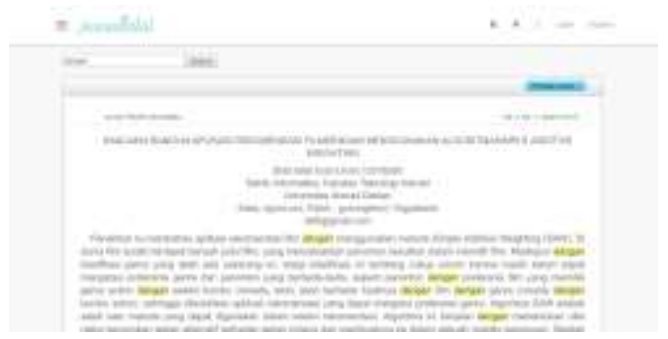

Gambar 12 : Tampilan Cari Kata

\subsection{Pengujian Sistem}

a. Black Box Test 
Melihat dari hasil lembar isian pengujian black box yang diberikan, dapat disimpulkan bahwa aplikasi berjalan sesuai dengan kebutuhan user yang telah dirancang.

b. Pengujian Post-Study

Rekapitulasi hasil kuisioner yang diberikan kepada penulis adalah sebagai berikut:

\begin{tabular}{|c|c|c|c|c|c|}
\hline Responden & q1 & q2 & q3 & q4 & q5 \\
\hline Res 1 & 4 & 2 & 5 & 2 & 5 \\
\hline Res 2 & 4 & 1 & 4 & 1 & 4 \\
\hline Res 3 & 5 & 1 & 4 & 2 & 4 \\
\hline Res4 & 4 & 1 & 4 & 1 & 4 \\
\hline Res 5 & 5 & 1 & 4 & 1 & 4 \\
\hline Res 6 & 5 & 1 & 4 & 1 & 5 \\
\hline Res 7 & 5 & 1 & 4 & 1 & 5 \\
\hline Res 8 & 5 & 1 & 5 & 1 & 5 \\
\hline Res 9 & 5 & 1 & 5 & 2 & 5 \\
\hline Res10 & 5 & 2 & 4 & 1 & 4 \\
\hline & & & & & \\
\hline & & & & & \\
\hline
\end{tabular}

\begin{tabular}{|c|c|c|c|c|c|}
\hline Res 11 & 5 & 2 & 5 & 1 & 4 \\
\hline Res 12 & 4 & 1 & 4 & 1 & 4 \\
\hline Res 13 & 4 & 1 & 4 & 1 & 4 \\
\hline Res 14 & 3 & 2 & 5 & 1 & 2 \\
\hline Res 15 & 4 & 1 & 5 & 1 & 5 \\
\hline
\end{tabular}

\begin{tabular}{|c|c|c|c|c|c|c|}
\hline Res 16 & 5 & 1 & 5 & 1 & 4 & 1 \\
\hline Res 17 & 4 & 2 & 5 & 2 & 4 & 2 \\
\hline Res 18 & 4 & 1 & 5 & 1 & 5 & 1 \\
\hline Res 19 & 4 & 2 & 5 & 1 & 5 & 1 \\
\hline
\end{tabular}




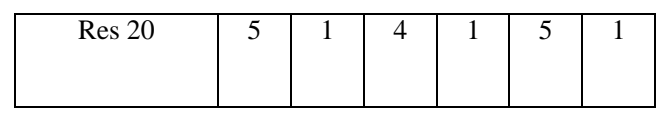

\begin{tabular}{|c|c|c|c|c|c|}
\hline Res 21 & 4 & 1 & 5 & 1 & 5 \\
\hline Res 22 & 4 & 1 & 5 & 1 & 4 \\
\hline Res 23 & 4 & 1 & 5 & 1 & 5 \\
\hline Res24 & 4 & 1 & 5 & 4 & 4 \\
\hline Res 25 & 4 & 4 & 5 & 2 & 3 \\
\hline Res 26 & 4 & 2 & 5 & 1 & 5 \\
\hline Res 27 & 4 & 2 & 4 & 2 & 3 \\
\hline Res 28 & 5 & 1 & 5 & 2 & 4 \\
\hline Res 29 & 4 & 1 & 5 & 2 & 5 \\
\hline Res 30 & 5 & 2 & 5 & 2 & 5 \\
& & & & & \\
\hline
\end{tabular}

Pertanyaan urutan ganjil (bernada positif), skor dihitung pada skala posisi dikurangi/minus 1 (xi -1). Pertanyaan urutan genap (bernada negatif), skor dihitung pada 5 dikurangi/minus skala posisi (5-xi) Skor SUS keseluruhan didapat dengan mengkalikan kontribusi skor item dengan 2.5 . Sehingga skor SUS keseluruhan berada pada range $0 . .100$ dengan penambahan atau inkremental setiap 2.5 poin.

Total Score SUS adalah :

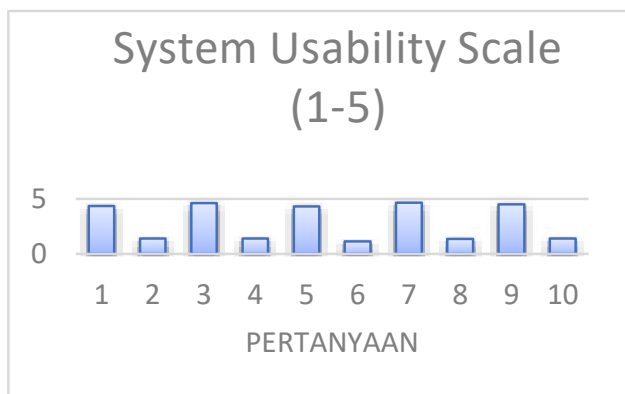

Jumlah skor yang di dapatkan dari semua responden :

(Jumlah Skor Yang di dapatkan dari semua responden)/(Jumlah Responden)

Didapatkan skor 89.58 (dengan sekala $0 . .100$ ). 100\% responden menyatakan sistema aplikasi bisa diterima (acceptable). Artinya berdasarkan rerata penilaian SUS responden sebesar 89,58 sistem aplikasi dinyatakan acceptable

Berdasarkan presentase dari 30 responden, $6 \%$ responden menyatakan aplikasi (sangat sulit) untuk digunakan. Hal tersebut disebabkan karena pengguna baru pertamakali mengunakan dan 
proses untk menulis jurnal, penulis di wajibkan untuk register terlebih dahulu dan menunggu konfirmasi dari dari redaksi jurnal.

Dari perhitungan diatas, dapat disimpulkan bahwa nilai rata - rata responden anggota adalah 89,58 maka aplikasi authoring tools jurnal berbasis web dinyatakan dapat diterima oleh pengguna (Acceptable).

\section{Penutup}

\subsection{Kesimpulan}

Berdasarkan hasil penelitian yang telah dilakukan, maka dapat disimpulkan sebagai berikut :

1. Telah dihasilkan Autoring tools jurnal berbasis web yang dapat mengedit, membuat, meriview dan membaca jurnal untuk memudahkan penulis, pembaca dan pengelola jurnal .

2. Aplikasi Autoring tools sudah melewati pengujian black box test dan usability.

3. Berdasarkan hasil pengujian Usability, aplikasi authoring tools jurnal berbasis web mendapatkan skor pengujian sebesar 89.58 (dengan skala $0 . .100$ ) maka dinyatakan acceptable yang artinya authoring tools jurnal berbasis web diterima dan dapat memuaskan kebutuhan pengguna.

\subsection{Saran}

Saran yang dapat disampaikan dari hasil peneitian yaitu dalam aplikasi authoring tools ini pada pembacaan jurnal 2 kolom mengunakan library mpdf mungkin bisa di kembangakan lagi mengunakan library lain atau membuat library sendiri.

\section{Daftar Pustaka}

[1] Gu, X., Wu, B., \& Xu, X. (2015). Design, development, and learning in e-Textbooks: what we learned and where we are going. Journal of Computers in Education, 2(1), 2541.http://doi.org/10.1007/s40692-014-0023-9Kotler, Philip, 2002, ManajemenPemasaran,Prenhalindo, Jakarta.

[2] Erhan, D. (2014). Effect of hypertextual reading on academic success and comprehension skills. Educational Research and Reviews, 9(14),447-455.http://doi.org/10.5897/ERR2013.1405

[3] Harmin, A. (2016). Authoring Tools Algoritma Dan Pemrograman Sebagai Media Pembelajaran On-Line Pada Stmik Profesional Makassar (Studi Kasus Matakuliah Algoritma Dan Pemrograman), 1-12.

[4] Sinung. (2014). Pengembangan native front- end aplikasi pembaca skripsi di perpustakaan kampus iii uad menggunakan android tablet.

[5] Realitha,Cindy.2012.Pengembangan Back-End System Pada Aplikasi Interactive E-book Reader Di Android Menggunakan Framework Phonegap.

[6] Singgih. (2015). Pengembangan user experience (ux) dan user interface (ui) sistem manajemen perpustakaan desa berbasis saas.

[7] Booch, G., Rumbaugh, J. \& Jacobson, I., 2005. The unified modeling language user guide Second Edition. , p.496.

[8] Sidiq, M. A. (2012). Content pada pengembangan CMS menggunakan codeigniter. Undergraduate thesis, Universitas Stikubank ( Unisbank ) Semarang.

[9] Sommerville, Ian , 2007, Software Engineering - Eight Edition, Addison Wesley, Massachussets.

[10] Gulzar, N., 20 Lukman, Ekawati Marlina, Ratih Keumalasari, Al Hafidz Akbar Maulana Siagian, S. R. (2012). Perkembangan Open Acces Jurnal Ilmiah Indonesia. Prosiding Konferensi Perpustakaan Digital Indonesia (KPDI) Ke-5, (January 2016), 1-8. https://doi.org/10.13140/2.1.1159.2009. 